удК 339.972

\title{
ГЛОБАЛЬНІ ІНСТРУМЕНТИ ПРОТИДІЇ ЕКОЛОГІЧНИМ ПРОБЛЕМАМ У СУЧАСНІЙ СИСТЕМІ СВІТОВОГО ГОСПОДАРСТВА
}

\section{GLOBAL INSTRUMENTS ADDRESSING ENVIRONMENTAL ISSUES IN THE MODERN GLOBAL ECONOMY}

\author{
Халавка Остап Андрійович \\ студент другого курсу магістратури, \\ Інститут міжнародних відносин \\ Київського національного університету імені Тараса Шевченка \\ ORCID: https://orcid.org/0000-0002-1412-3672 \\ Поліщук Ліна Сергіївна \\ кандидат економічних наук, доцент, \\ Інститут міжнародних відносин \\ Київського національного університету імені Тараса Шевченка \\ ORCID: https://orcid.org/0000-0003-4458-8304
}

Khalavka Ostap, Polishchuk Lina

Institute of International Relations of the

Taras Shevchenko National University of Kyiv

\begin{abstract}
У сучасній системі світового господарства проблема забруднення навколишнього середовища набула загрозливого характеру для довгострокового економічного розвитку як розвинутих країн світу, так і країн, що розвиваються. Ключовими інструментами протидії екологічним проблемам у сучасній системі світового господарства та міжнародних економічних відносин слугують Паризька Кліматична Угода, Цілі Сталого Розвитку ООН та система торгівлі квотами на викиди. Існуючі глобальні інструменти протидії екологічним загрозам демонструють недостатню ефективність у досягнення поставлених перед ними цілей, а тому потребують перегляду. Ключовим недоліком наявних інструментів $€$ відсутність обов'язкового характеру для країн-підписантів, а також недосконалість механізмів моніторингу та контролю за станом їх реалізації. Підвищення ефективності наявних глобальних інструментів протидії екологічним проблемам та розробка більш дієвих інструментів повинні стати пріоритетом для акторів сучасної системи світового господарства.
\end{abstract}

Ключові слова: сталий розвиток, світове господарство, глобальні інструменти протидії екологічним проблемам, забруднення навколишнього середовища, світова спільнота, викиди.

В современной системе мирового хозяйства проблема загрязнения окружающей среды приобрела угрожающий характер для долгосрочного экономического развития как развитых стран мира, так и развивающихся стран. Ключевыми инструментами противодействия экологическим проблемам в современной системе мирового хозяйства и международных экономических отношений служат Парижская Климатическое Соглашение, Цели Устойчивого Развития ООН и система торговли квотами на выбросы. Существующие глобальные инструменты противодействия экологическим угрозам демонстрируют недостаточную эфрфективность в достижении поставленных перед ними целей, а потому нуждаются в пересмотре. Ключевым недостатком имеющихся инструментов является отсутствие обязательного характера для стран-подписантов, а также несовершенство механизмов мониторинга и контроля за состоянием их реализации. Повышение эффеективности имеющихся глобальных инструментов противодействия экологическим проблемам и разработка наиболее эффективных инструментов должны стать приоритетом для актеров современной системы мирового хозяйства.

Ключевые слова: устойчивое развитие, мировое хозяйство, глобальные инструменты противодействия экологическим проблемам, загрязнение окружающей среды, мировое сообщество, выбросы.

In the modern global economic system, the issue of environmental pollution poses a significant threat to the long-term economic development projections of both developed and developing countries. Environmental pollution causes not only financial damage to the global economy but also affects the quality of life of citizens and their health 
conditions that may create long-term challenges for healthcare systems worldwide. The list of the main global instruments addressing environmental issues in the modern economy includes UN Sustainable Development Goals, Paris Climate Agreement, and the system of emission trading. The UN Sustainable Development Goals encompass extremely broad area of work for countries and needs to be done to ensure sustainable economic growth in the world and increase the level of welfare of citizens worldwide. The Paris Climate Agreement is aimed at mitigating the negative effects of climate change through the implementation of sustainable initiatives. The emission trading system constitutes a way for economic actors to ensure harmonized economic development worldwide. Although the majority of countries have accepted these instruments and integrated them in their national economic policies, the global community has not achieved visible progress in making global economy more sustainable. The existing global instruments addressing environmental issues are not effective enough to achieve the prescribed targets and objectives and, thus, they need to be revised. The main shortcomings related to these global instruments are their non-mandatory nature for parties and inefficiency of the mechanisms of monitoring and control of their implementation. Moreover, not all countries have enough financial resources and expertise to fully implement them. The global economic actors should strive to increase the efficiency of the existing global instruments addressing environmental issues and develop more effective ones. The global economic community needs to realize that sustainable development may bring much more benefits than the costs associated with its achievement. Generally, the innovative and rapid development of the global economy cannot take place unless countries worldwide realize the importance of the concept of sustainability.

Keywords: sustainable development, global economy, global instruments addressing environmental issues, environmental pollution, global community, emissions.

Постановка проблеми. Ефективність існуючих глобальних інструментів протидії екологічним проблемам $€$ недостатньою, а тому оцінка можливості для їх вдосконалення у призмі існуючого стану розвитку світового господарства та в контексті намагання світової спільноти досягти сталого розвитку є особливо актуальною.

Аналіз останніх досліджень і публікацій. Основні дослідження на дану тематику здійснюються міжнародними організаціями, зокрема Програмою Розвитку ООН та групою Світового Банку, а також міжнародними фрахівцями у галузі сталого розвитку. Відомий канадський експерт з питань корпоративної соціальної відповідальності підприємств, що функціонують у видобувній галузі, зазначає, що за умови інтеграції Цілей Сталого Розвитку у свою довгострокову бізнес стратегію, компанії зможуть не лише покращити свій імідж та репутацію, але й підвищити свою конкурентоспроможність як на національному, так і на міжнародному рівнях [1]. У свою чергу, група китайських вчених на чолі із Чангом Хайбіном зазначають, що вирішення глобальних екологічних проблем знаходиться більше у парадигмі політики, а не економіки, а тому будь-які політичні рішення ухвалені керівництвом провідних держав, зокрема США або Китаю, можуть значною мірою впливати на ефективність глобальних інструментів протидії екологічним проблемам [4]. Питання вирішення глобальних екологічних проблем також активно досліджується вітчизняними науковцями, зокрема проф. Резніковою Н.В.

Невирішеними раніше частинами загальної проблеми $€$ оцінка ефективності існуючих глобальних інструментів протидії екологічним проблемам у контексті глобалізаційних процесів, які стикають із проявами протекціонізму з боку окремих суб'єктів світового господарства.

Цілі статті: проаналізувати ефрективність існуючих глобальних інструментів протидії екологічним проблемам та оцінити потенціал для їх вдосконалення.

Виклад основного матеріалу. У 2015 р. усі країни-члени ООН прийняли Програму Сталого Розвитку 2030. В основі даного документа лежать 17 Цілей сталого розвитку, які повинні стимулювати як країни, що розвиваються, так і розвинуті країни, співпрацювати на глобальному рівні для їх досягнення [1, с. 790]. Подолання бідності та глобальної нерівності повинно супроводжуватись покращенням медицини та посиленням освітньої галузі, що, у свою чергу, стане каталізатором економічного зростання, яке сприятиме збільшенню загального добробуту лише за умови, що людство досягне успіху у питанні протидії змінам клімату та збереження природніх ресурсів. Щорічно в рамках ООН на найвищому рівні проходить Політичний Форум щодо Сталого Розвитку, який слугує основною платфрормою для обговорення та моніторингу досягнення Цілей Розвитку ООН. Розглянемо детальніше ті Цілі Сталого Розвитку, які безпосередньо пов'язані з екорозвитком.

- Чиста вода та належні санітарні умови: забезпечення доступу населення до недорогої та безпечної питної води через відновлення водних екосистем, зокрема, лісів, річок, боліт та озер. Ключовою метою даної цілі є подолання дефріциту води. 
- Відновлювана енергія: у зв'язку із зростанням чисельності населення, різко зросте попит на дешеву енергію. Близько п'ятої частини населення планети не має доступу до електроенергії, а тому необхідно збільшувати виробництво електроенергії із відновлюваних джерел завдяки інвестиціям. Особливу увагу слід звернути на модернізацію технологічної бази та інсрраструктури в країнах, що розвиваються.

- Сталий розвиток міст і спільнот: більше половини населення світу проживає у містах. Забезпечення сталого розвитку міст потребує інвестицій у екологічний транспорт, створення зелених громадських зон та впровадження енергозберігаючих технологій.

- Відповідальне споживання: розробка технології безпечної утилізації небезпечних відходів для здоров'я населення та речовин, що забруднюють природні екосистеми. Необхідно не лише стимулювати підприємства та великі корпорації скорочувати обсяги згенерованих викидів, але й розробляти і впроваджувати моделі раціонального споживання у країнах, що розвиваються.

- Боротьба зі зміною клімату: наразі обсяги викидів парникових газів перевищують на 50\% показники 1990 р. На рівні регіонів, держав та локалітетів необхідно вживати заходів задля досягнення нульового рівня викидів вуглецю, а також його утримання в землі при видобутку корисних копалин. Необхідно застосовувати методи раннього попередження та захисту від негативних природних явищ, зокрема повеней.

- Збереження морських екосистем: морські екосистеми забезпечують існування понад 3 мільярдів людей у різних країнах світу. Морські екосистеми поглинають понад 30\% вуглекислого газу, а тому їх збереження і підтримка повинні постійно перебувати у порядку денному світової спільноти. Необхідно сприяти раціональному господарювання та захисту прибережних і морських екосистем від антропогенного забруднення та закислення.

- Партнерство заради стійкого розвитку: Найменш розвинуті країни світу потребують міжнародної фрінансової допомоги задля реалізації даних цілей. Міжнародне партнерство повинно сприяти забезпеченню доступу усіх суб'єктів світового господарства до технологій та знань, а також інновацій у ссрері сталого розвитку.

Основна критика Цілей Сталого Розвитку ООН стосується їх акценту на довгостроковий характер, що, у випадку забруднення навколишнього середовища, може мати згуб- ний вплив як на стан екосистеми, так і на здоров'я людей. Цілі Сталого Розвитку ООН, окрім 2030 р., не встановлюють чітких часових рамок для впровадження конкретних ініціатив. Саме тому існує загроза, що більшість акторів світового господарства максимально відтягуватимуть процес запровадження моделей екорозвитку 3 метою максимізації свого прибутку у короткостроковій перспективі.

Недостатньо уваги Цілі Сталого Розвитку ООН звертають на локальні особливості окремих регіонів та менталітет їх населення. Ключовим недоліком системи ООН в цілому, та Цілей Сталого Розвитку, зокрема, є брак достовірної та релевантної інфрормації. Зважаючи на бюрократичний характер, $\mathrm{OOH}$ не володіє достовірною інформацією щодо стану забруднення глобального навколишнього середовища та негативного впливу на нього світового господарства. На локальному рівні, зв'язок між національними урядами та експертами ООН не $є$ досконалим, а регіональні представництва організації відіграють незначний вплив на суспільну думку та бізнес. Саме тому Цілі Сталого Розвитку ООН не слід вважати дієвим інструментом протидії сучасним екологічним викликам.

Зважаючи на описовий характер Цілей сталого розвитку ООН, більш дієвим міжнародним інструментом протидії екологічним проблемам у сучасній системі світового господарства можна вважати Паризьку Кліматичну Угоду. Паризька Кліматична Угода $є$ першим глобальним документом обов'язкового характеру, спрямованим на протидію змінам клімату, який було прийнято на Паризькій кліматичній конференції у 2015 р. Понад 190 країн світу, зокрема $€ С$ та його члени, стали учасниками даної Угоди. Для вступу в дію Паризької Кліматичної Угоди необхідна була її ратифрікація принаймні 55 країнами світу, які сумарно продукують понад 55\% усіх викидів планети [3]. Також даний інструмент надає державам більші повноваження щодо протидії змінам клімату, а також забезпечує їм всебічну підтримку у імплементації національних стратегій протидії змінам клімату. Загалом, Паризьку Кліматичну Угоду можна розглядати як своєрідний сполучник між теперішніми національними стратегіями протидії змінам клімату та екологічно-нейтральним розвитком, який світова спільнота прагне досягти до завершення XXI ст. Паризька Кліматична Угода передбачає довгострокову ціль збереження підвищення середньої температури повітря у межах до 2 градусів Цельсія у порівнянні із 
доіндустріальними показниками та поступове скорочення викидів до нейтральних показників після 2050 р. [3].

Держави-учасниці даної Угоди також зобов'язались всіляко підтримувати держави, що розвиваються, у їх прагненні впроваджувати екологоорієнтовані зміни, спрямовані на досягнення цілей Угоди. Ключову роль, окрім держав-учасниць, у реалізації даної Угоди відіграють такі сторони як міста, громадянське суспільство, уряди локалітетів та приватний сектор. Ключовою метою діяльності недержавних сторін даної Угоди є посилення їх протидії та спрямування зусиль щодо мінімізації негативного впливу змін клімату на сучасну систему світового господарства. Загалом, для досягнення цілей Паризької Кліматичної Угоди високорозвинуті держави світу зобов'язались щорічно виділяти 100 млрд дол США. Саме тому Паризьку Кліматичну Угоду можна вважати і масштабним інвестиційним проєктом.

Слід зазначити, що керівництво США в особі колишнього Президента Д. Трампа прийняло рішення про вихід з Угоди і датою вступу в силу даного рішення було 4 листопада 2020 р. Водночас, Росія, Туреччина та Іран, які вважаються одними із найбільших забруднювачів навколишнього середовища, не приєднались до Угоди. Причиною небажання Д. Трампа дотримуватись умов Паризької Кліматичної Угоди є його думка, що сірим кардиналом і головним їі бенефіціаром може бути Китай [4, с. 222]. Також, за оцінкою Д. Трампа, збитки для економіки США, спричинені участю країни у Паризькій Кліматичній Угоді, до 2040 р. складуть 3 трлн дол США, а 2,7 млн американців втратять роботу до 2025 р. Як наслідок, на думку Трампа, США можуть опинитись у неконкурентному положенні по відношенню до Індії та Китаю, які отримають нові конкурентні переваги над економікою США. Проте, міста, регіональні організації та громадськість у США, у переважній більшості, виступили за збереження членства США в Угоді. Одразу після вступу на посаду, новий Президент США Д. Байден підписав указ про повернення США до Паризької Кліматичної Угоди.

Щодо зобов'язань окремих держав-учасниць Паризької Кліматичної Угоди, варто зазначити, що вони різняться. Наприклад, Китай зобов'язався скоротити викиди вуглеця у перерахунку на 1 од. ВВП на 60\%$65 \%$ до 2030 р. у порівнянні із показниками 2005 р. Індія, у свою чергу, встановила дещо нижчі орієнтири на рівні 33\%-35\%, однак, зобов'язалась генерувати 40\% електроенергії із відновлюваних джерел [5]. США, до прийняття рішення щодо виходу із Паризької Кліматичної Угоди, зобов'язались скоротити викиди парникових газів в атмосфреру на 26\%$28 \%$ до 2025 р.

Слід зазначити, що більшість підписантів Паризької КліматичноїУгоди, наданий момент, не досягають поставлених перед собою цілей щодо скорочення викидів. Серед 5 найбільших забруднювачів навколишнього середовища, лише ЄС досягає цільових показників щодо зменшення викидів на 40\% до 2030 р. і має спроможність довести даний показник до 60\% до 2030 р. [5]. Загалом, серед усіх країн-учасників Паризької Кліматичної Угоди, 130 держав не досягають планових показників скорочення рівня викидів. В результаті неспроможності держав досягти планових скорочень викидів, економічні збитки для світового господарства від природних явищ, спричинених забрудненням навколишнього середовища, можуть сягнути 2 млрд дол США у день або 660 млрд дол США щорічно до 2030 р. [6]. Ключовою причиною неспроможності або небажання держав досягнути поставлених перед ними цілей щодо скорочення викидів $€$ їх необов'язковий характер.

Після ратифрікації Паризької Кліматичної Угоди у 2015-2016 рр., лише 4 країни світу, зокрема Аргентина, Марокко, Еквадор та Маршалові Острови, переглянули свої цілі щодо скорочення викидів у бік збільшення, a усі інші країни-підписанти Угоди залишили їх незмінними або, як у випадку Еритреї та Беніну, знизили їх. Лише 26\% усіх підписантів Угоди встановили такі цілі щодо зменшення викидів, які є достатніми для скорочення глобального рівня викидів, у той же час, 76\% усіх підписантів встановили цілі нижче порогового рівня, а тому вони не матимуть позитивного впливу на рівень глобальних викидів [5]. Саме низькі цілі, встановлені підписантами Паризької Угоди становлять значну перешкоду на шляху до суттєвого скорочення рівня викидів у сучасній системі світового господарства.

Варто зазначити, що навіть деякі країни із високим рівнем доходу, зокрема Об'єднані Арабські Емірати, Саудівська Аравія, Катар, Кувейт, Бахрейн та Антигуа і Барбуда не ставили перед собою жодних цілей щодо скорочення викидів. Також, цілі щодо зменшення викидів таких країн як Венесуела, Сейшели, Уганда, Оман, Пакистан та ряду інших країн на 100\% залежать від зовнішньої матеріально-технічної допомоги, а тому зусилля 
даних країн щодо зменшення викидів можна вважати недостатніми [5]. Україна відноситься до переліку тих держав, які встановили достатні цілі щодо зменшення обсягу викидів. Ціллю України є скорочення викидів до такого рівня, за якого вони не перевищуватимуть 60\% показників 1990 р. [3]. Однак, слід розуміти, що левова частина викидів 1990 р. продукувалась підприємствами, які, зважаючи на особливості соціально-економічного розвитку України протягом останніх десятиліть, припинили свою діяльність. Фактично, скорочення викидів в Україні у порівнянні із 1990 р. відбувається не стільки за рахунок модернізації економіки та реалізації програм енергоефективності, а у зв'язку з деіндустріалізацією.

У контексті аналізу глобальних інструментів протидії екологічним проблемам доречно згадати про такий інструмент як торгівля викидами. Торгівлю викидами також можна назвати екологічним податком. Торгівля викидами сприяє економічній ефективності, створює умови для скорочення викидів у тих регіонах і країнах, де цього найлегше досягти. Ті ж країни, які не в змозі скоротити обсяги викидів, мають право придбати у країн, яким вдалось скоротити обсяг викидів, певний обсяг невикористаних викидів.

На глобальному рівні, 39 держав та 23 субнаціональні юрисдикції прийняли або планують прийняти інструменти протидії екологічним небезпекам шляхом торгівлі викидами. Найбільшим ринком торгівлі викидами $є$ Європейська система торгівлі викидами, яка об'єднує країни-члени ЄС. У сучасній системі світового господарства, торгівля викидами регулюється Статтею 6 Паризької Кліматичної Угоди [3]. Однією із ключових цілей Паризької Кліматичної Угоди у контексті торгівлі викидами є активне залучення приватного сектору. Загалом, механізм торгівлі викидами є важливим інструментом протидії екологічним загрозам, однак, основними недоліками даної системи є нечіткий механізм підрахунку викидів.

Висновки. Основними глобальними інструментами протидії екологічним проблемам $€$ Цілі Сталого Розвитку ООН, Паризька Кліматична Угода та система торгівлі квотами на викиди. Основним недоліком Цілей Сталого Розвитку $\mathrm{OOH} є$ загальний характер та відсутність механізмів санкцій проти держав, які не виконують взятих на себе зобов'язань. Серед основних недоліків Паризької Кліматичної Угоди є вихід США із неї та нерівномірність зобов'язань, взятих на себе кожною країною. Ключовим недоліком системи торгівлі квотами є її неефективність у питанні подолання глобальних проблем забруднення навколишнього середовища, оскільки, на практиці, відбувається передача забруднення між країнами, а механізму ізоляції окремих держав від глобальних екологічних проблем не існує. Подальші дослідження у даному напрямку повинні бути спрямовані на перегляд зобов'язань взяти на себе країнамипідписантами даних інструментів у контексті відновлення світового господарства після коронавірусного економічного потрясіння та аналіз впливу коронакризи на ефективність існуючих глобальних інструментів протидії екологічним проблемам.

\section{СПИСОК ВИКОРИСТАНИХ ДЖЕРЕЛ:}

1. Fraser, J. (2019). Creating shared value as a business strategy for mining to advance the United Nations Sustainable Development Goals. The Extractive Industries and Society, 6(3), 788-791.

2. United Nations Development Programme (2020). Sustainable development goals. URL: https://www.undp.org/ content/undp/en/home/sustainable-development-goals.html

3. Паризька Угода / Верховна Рада України. URL: https://zakon.rada.gov.ua/laws/show/995_I61\#Text (дата звернення: 10.01.2021).

4. Zhang, H. B., Dai, H. C., Lai, H. X., \& Wang, W. T. (2017). US withdrawal from the Paris Agreement: Reasons, impacts, and China's response. Advances in Climate Change Research, 8(4), 220-225.

5. Carbon Brief (2020). Paris 2015: Tracking country climate pledges. URL: https://www.carbonbrief.org/paris2015-tracking-country-climate-pledges

6. Leahy, S. (2019). "Most countries aren't hitting 2030 climate goals, and everyone will pay the price". National Geographic. URL: https://www.nationalgeographic.com/science/2019/11/nations-miss-paris-targets-climate-drivenweather-events-cost-billions/ 


\section{REFERENCES:}

1. Fraser, J. (2019). Creating shared value as a business strategy for mining to advance the United Nations Sustainable Development Goals. The Extractive Industries and Society, 6(3), 788-791.

2. United Nations Development Programme (2020). Sustainable development goals. URL: https://www.undp.org/ content/undp/en/home/sustainable-development-goals.html

3. Verkhovna Rada of Ukraine (2016). Paryzjka Ughoda. Available at: https://zakon.rada.gov.ua/laws/show/995_ I61\#Text (accessed 10 January 2021).

4. Zhang, H. B., Dai, H. C., Lai, H. X., \& Wang, W. T. (2017). US withdrawal from the Paris Agreement: Reasons, impacts, and China's response. Advances in Climate Change Research, 8(4), 220-225.

5. Carbon Brief (2020). Paris 2015: Tracking country climate pledges. URL: https://www.carbonbrief.org/paris2015-tracking-country-climate-pledges

6. Leahy, S. (2019). "Most countries aren't hitting 2030 climate goals, and everyone will pay the price". National Geographic. URL: https://www.nationalgeographic.com/science/2019/11/nations-miss-paris-targets-climate-drivenweather-events-cost-billions/ 